\title{
LITHUANIAN CASE STUDY OF MASONRY BUILDINGS FROM THE SOVIET PERIOD
}

\author{
Willem Karel M. Brauers ${ }^{1}$, Modestas Kracka ${ }^{2}$, Edmundas Kazimieras Zavadskas ${ }^{3}$ \\ ${ }^{1}$ Faculty of Applied Economics, University of Antwerp, Prinsstraat 13, B2000 Antwerpen, Belgium \\ ${ }^{2,3}$ Department of Construction Technology and Management, Vilnius Gediminas Technical University, \\ Saulètekio al. 11, LT-10223 Vilnius, Lithuania \\ E-mails: ${ }^{1}$ willem.brauers@ua.ac.be (corresponding author); ${ }^{2}$ modestas.kracka@vgtu.lt; \\ ${ }^{3}$ edmundas.zavadskas@vgtu.lt
}

Received 27 Dec. 2011; accepted 27 Feb. 2012

\begin{abstract}
This paper presents the process of effective selection of building elements for renovation important for energy saving in buildings. A large part of energy is lost in non-effective buildings. Therefore, in renovation of buildings, it is important to select effective structural improvements. Building insulation could not only save energy but also time, money and materials, which means that different objectives expressed in different units have to be fulfilled. Although different methods exist for the application of Multi Objective Optimisation, MULTIMOORA, which is composed of three submethods - Ratio System, Reference Point Method that uses ratios from the ratio system, and the Full Multiplicative Form-was preferred. Consequently, different solutions for building envelope renovation were ranked by MULTIMOORA as applied for masonry buildings from the Soviet period.
\end{abstract}

Keywords: thermal renovation, decision making, building envelope, insulation, Ratio System, Reference Point Method, Full Multiplicative Form, MULTIMOORA.

\section{Introduction}

This paper discusses the traditional way of construction specific to the Soviet period. Soviet period means the period before the independence of Lithuania in 1990. The average lifetime of a building is one hundred year (STR. 1.12.06:2002). Consequently the buildings of the Soviet period have still some lifetime.

Over time, the quality requirements and characteristics pertaining to building structures changed. We know the increasing importance of dry construction and of stricter requirements for thermal insulation appeared during the past decades.

In 2007, the European Council adopted ambitious energy and climate change objectives for 2020 - to reduce greenhouse gas emissions by $20 \%$ if the conditions are right, to increase the share of renewable energy to $20 \%$ and to make a $20 \%$ improvement in energy effectiveness. By 2020, the EU aims to reach that all new constructions and renovations would be passive (less than $15 \mathrm{kWh} / \mathrm{m}^{2}$ per year). The European Parliament has continuously supported these goals. The European Council has also given a long term commitment to the decarbonisation path with a target for the EU and other industrialised countries of 80 to $95 \%$ cuts in emissions by 2050 (European Commission 2011).

Many countries have their own directives. For instance: BREEAM (Building Research Establishment Environmental Assessment Method) in Great Britain; LEED (Leader Energy Environment Design) in the USA; HQE (High Environmental Quality) in France; MINERGIE in
Switzerland; PASSIVHAUS in Germany; HB BEAM in Hong Kong; CASBEE (Comprehensive Assessment System for Building Environmental Efficiency) in Japan and TOTAL QUALITY in Austria. All directives attempt to reach the sustainability in construction, however in different ways.

Cost of heating is one of the most important factors that influence the real estate market (Huang, Hsueh 2010). Thermal renovation of a building can significantly reduce heat losses and costs, thereby increasing the market value of such building. Although renovation does not necessarily increase energy effectiveness, it is a useful instrument that helps upgrading thermal performance.

Reduction of building energy consumption can be carried out in several stages namely: architectural optimisation of the building, and optimisation of building engineering systems. For architectural optimisation, properly selected building structures, orientation of partitions in respect to compass points, size of windows and thermal storage capabilities of devices are of the utmost importance (Motuziene, Juodis 2010; Kaklauskas et al. 2008; Kalibatas et al. 2011; Flores-Colen, de Brito 2010). Improvements under the form of optimized heat inflows and of heat losses allow reduced consumption of power for heating.

In order to select a rational alternative for renovation of building, is it necessary to investigate and to assess the conditions of the building, as well as to analyse investments.

The degree of deterioration of a building can be determined by the following studies: 
- Prior to the inspection stage - an opinion poll of residents regarding the physical, economic and functional deterioration of the building;

- Investigation of the technical condition of elements of the building (i.e. walls, windows, roof and floors);

- Study of energy supply and more effective fuel utilisation;

- Investigation of the condition of engineering equipment;

- During the investigation - an inventory of reasons for renovation, expected activities and tools that can improve characteristics of the building.

Every building is different in its construction, architecture, purpose, and needs of residents. Therefore, there cannot be one solution that would fit all buildings. Limiting the research only to residential buildings without considering commercial or public buildings forms a first step is to diminish these differences.

Evaluation of renovation possibilities is a difficult task as a building and its environment form complex systems (for instance in terms of technical, technological, ecological, social, comfort and aesthetical conditions). All subsystems influence the total effective performance and the interdependence between sub- systems plays a significant role.

Successful choice of a renovation measures depends on the following three stages:

- During the first stage, the elements of building envelope for renovation are determined;

- During the second stage, top-ranked alternatives for building envelope renovation are chosen;

- During the third stage, effective alternatives are selected by multiple objectives analysis in order to obtain alternative priorities and an alternative level of performance.

Building insulation is a safe choice that helps preventing damage to a building and improves energy saving undertaken in different parts of the building.

Insulation of the building will be studied as a function of the different partitions of the building: walls, windows, roofs and ceilings. Prior to renovation works, it is important to identify the existing state of walls, roof, floors, windows, doors and other building elements, as well as technical characteristics, i.e. materials, thickness of structures and orientation in respect of compass points (Tupenaite et al. 2010; Pasanisi, Ojalvo 2008). Such assessment of existing structures and complex exploration of building characteristics helps deciding on partitions that require further improvement and identifying changes that would be effective.

Parts of building envelope are assessed with respect to their degree of insulation and the impact of such insulation on reduction of heating costs. Sometimes, calculations reveal that modification of building structures is not effective due to a lengthy payback period that considerably exceeds heat losses for the partition. A multiple objective decision support system has been designed to properly select and implement thermal effectiveness tools for a building.

\section{The scope of the existing problem}

Sixty years ago, masonry buildings were the most popular in the Eastern Europe. Typically, the envelope of such buildings had no insulation (Figs 1-3). The built-up area was $10 \mathrm{~m}$ width to $50 \mathrm{~m}$ length. A five-storey building was selected for the analysis. From ceiling to ceiling, the height of a storey was $2.85 \mathrm{~m}$. The building had 90 windows in total: 45 windows facing north and the remaining 45 facing south. The building was ventilated in the natural way. Heating networks from a central heating unit of the city supplied heating to the building. Now obsolete heat network pipes are changed to new ones.

The thermal insulation performance of such a building is rather poor and does not comply with the current hygienic requirements. The main important areas of reduced masonry thicknesses are situated along the wall and slab juncture as demonstrated in Fig. 1; along the edge of the roof as shown in Fig. 2; and along the basement and slab (Fig. 3); and windows (not represented in Figs.). The building was designed with a large part of windows facing north. Because of thin masonry thickness in the partition juncture, thermal bridges cause low surface temperature, which could present a risk for mould growth. Condensation can cause dampness together with favorable temperature, mostly cause mould grow up.

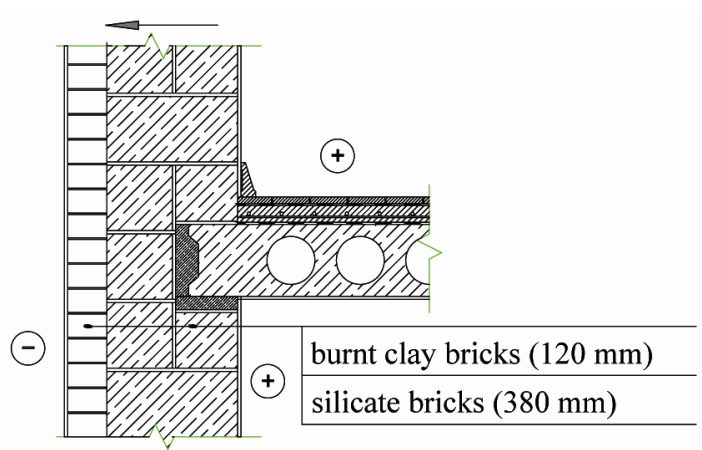

Fig. 1. Vertical section of the wall before renovation. The wall consist of two masonry layers, the first is $380 \mathrm{~mm}$ in width and the second is $120 \mathrm{~mm}$ in width

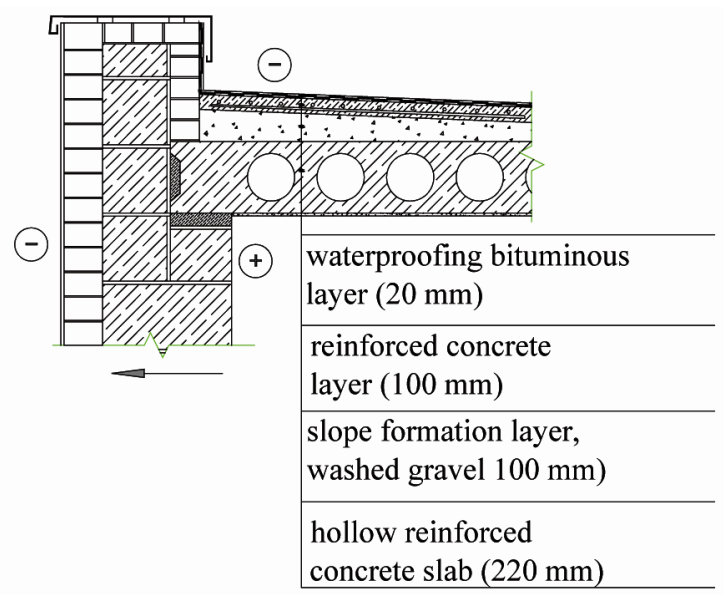

Fig. 2. Cross section of the roof before renovation. The roof detail consists of a hollow concrete slab, sand, and a waterproof bituminous layer 


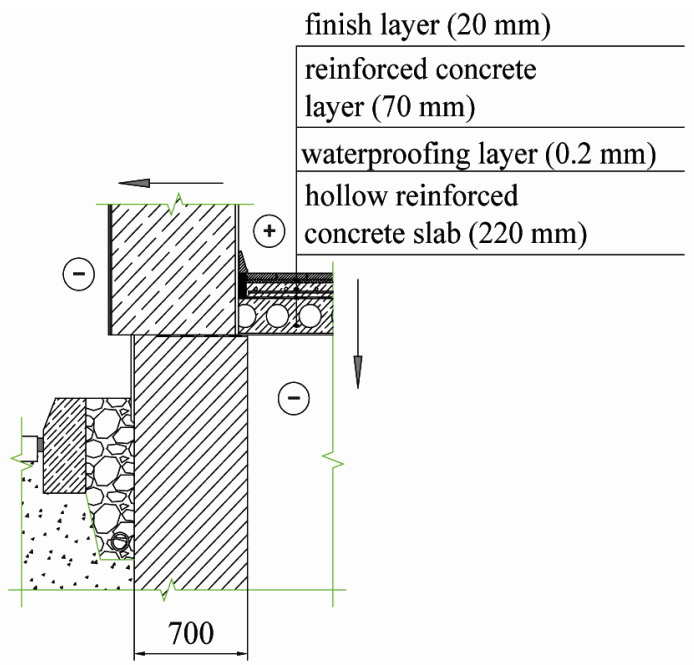

Fig. 3. Vertical section of the cellar ceiling before renovation. The ceiling consist of a hollow concrete slab of $220 \mathrm{~mm}$, waterproofing layer, a reinforced concrete layer of $70 \mathrm{~mm}$ and a finish layer of $20 \mathrm{~mm}$

The main purpose of this study is to assess elements of the building envelope using multiple objective models. Heating energy losses and inflows were calculated using equations from the technical construction regulation (STR.2.05.01:2005). A residential building has been chosen for this reason, with partition characteristics listed in Table 1.

Table 1. Heat losses through existing partitions

\begin{tabular}{c|l|c}
\hline No. & \multicolumn{1}{|c}{ Heat losses } & $\begin{array}{c}\text { Calculated values } \\
\left(\mathrm{kWh} / \mathrm{m}^{2} \text { per year }\right)\end{array}$ \\
\hline 1 & Heat losses through the walls & 90.21 \\
\hline 2 & Heat losses through the roof & 73.69 \\
\hline 3 & $\begin{array}{l}\text { Heat losses through the insulated } \\
\text { cellar ceilings }\end{array}$ & 14.84 \\
\hline 4 & Heat losses through the windows & 68.29 \\
\hline 5 & $\begin{array}{l}\text { Heat losses through the external } \\
\text { doors }\end{array}$ & 0.36 \\
\hline 6 & $\begin{array}{l}\text { Heat losses through the bearer } \\
\text { thermal bridges }\end{array}$ & 32.40 \\
\hline 7 & $\begin{array}{l}\text { Heat losses through opening } \\
\text { external doors }\end{array}$ & 24.04 \\
\hline 8 & $\begin{array}{l}\text { Energy consumption for natural } \\
\text { ventilation of the building }\end{array}$ & 75.64 \\
\hline 9 & $\begin{array}{l}\text { Heat losses through the external } \\
\text { air infiltration }\end{array}$ & -28.76 \\
\hline 10 & Heat inflows in the building & -6.34 \\
\hline 11 & $\begin{array}{l}\text { Internal heat divergence in the } \\
\text { building }\end{array}$ & $\begin{array}{l}\text { Total energy consumption in the } \\
\text { building (without the assessment } \\
\text { of the efficiency of the heating } \\
\text { system) }\end{array}$ \\
\hline
\end{tabular}

\section{Complex renovation of building partitions}

Often, thermal insulation layers were selected for each partition individually, but the final result was often neither accurate nor effective. Authors of the paper offer a methodology that helps selecting complex heat insulation layers for the entire building. Complex thermal insulation selection helps to estimate better payback time of the insulation, lost heat amounts and durability.

The method for insulation of building envelope is selected depending on the structure, building materials and the purpose of the partition as well as other objectives. Exterior insulation (Figs 5, 6) is the best way for elimination of thermal bridges in wall and ceiling junctures. With the help of the exterior wall insulation, the existing wall structure falls within the positive temperature range. In addition, the wall gets protected from atmospheric and other external effects (Fig. 4). Thermal renovation of the facade doesn't require a temporary removal of residents and the work can be done quickly. Renovated facade is more resistant to atmospheric impacts and has a greater aesthetic value.

Wall insulation from inside can be used for various buildings, especially for heritage buildings. Heritage building means a building possessing historical, architectural or cultural values. A heritage building is declared by Competent Authority in whose jurisdiction such building is situated.

Internal wall insulation, in terms of thermal and humidity effectiveness, is less effective. A wall supporting structure, which is insulated from the inside, has significant temperature fluctuations. This is due to external climate impact. Consequently operational conditions deteriorate. To avoid the risk of condensation, it is not recommended to install interior thermal insulation that would be wider than $5 \mathrm{~cm}$. Internal wall insulation reduces the living space, requires recoating of walls and reinstallation of engineering equipment (Golic et al. 2011).

Insulation improvements should ensure that thermal insulation layers of different partitions connect and overlap. New insulation layer placed onto the wall has to be connected or overlap the insulation layer placed onto the roof.

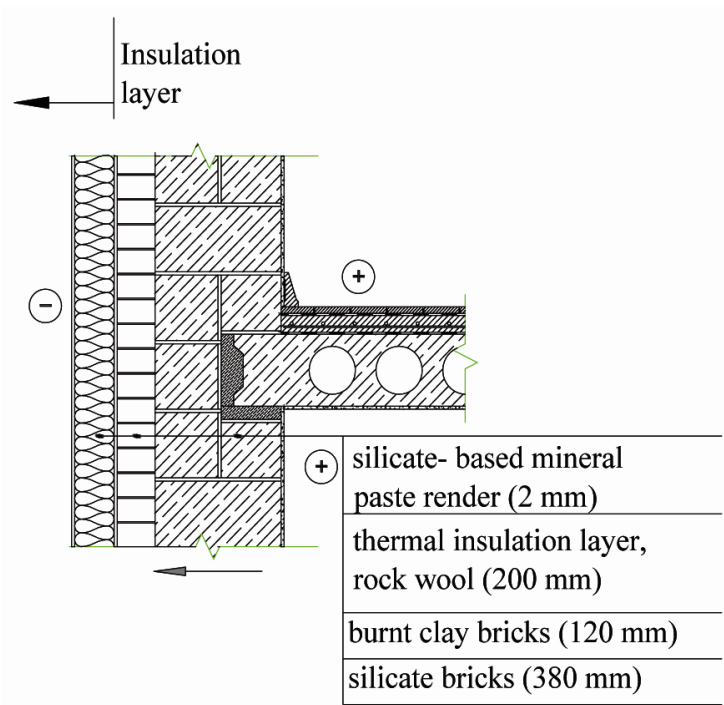

Fig. 4. Improvement of the thermal insulation layer $(200 \mathrm{~mm}$ in width) on walls of the building. Thermal bridge is eliminated along the wall and slab juncture 


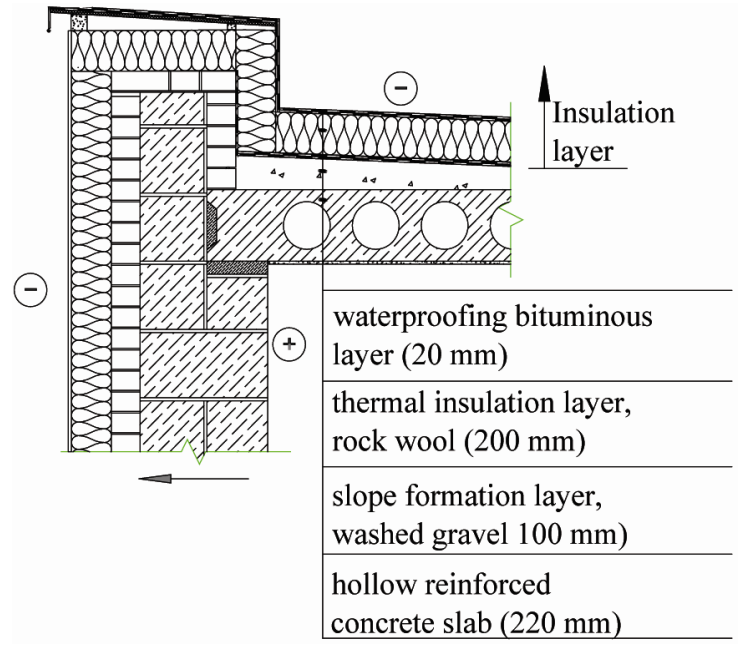

Fig. 5. Improvement of the thermal insulation layer $(200 \mathrm{~mm}$ in width) on the roof of the building. The external insulation layer on walls is connected to the insulation layer on the roof

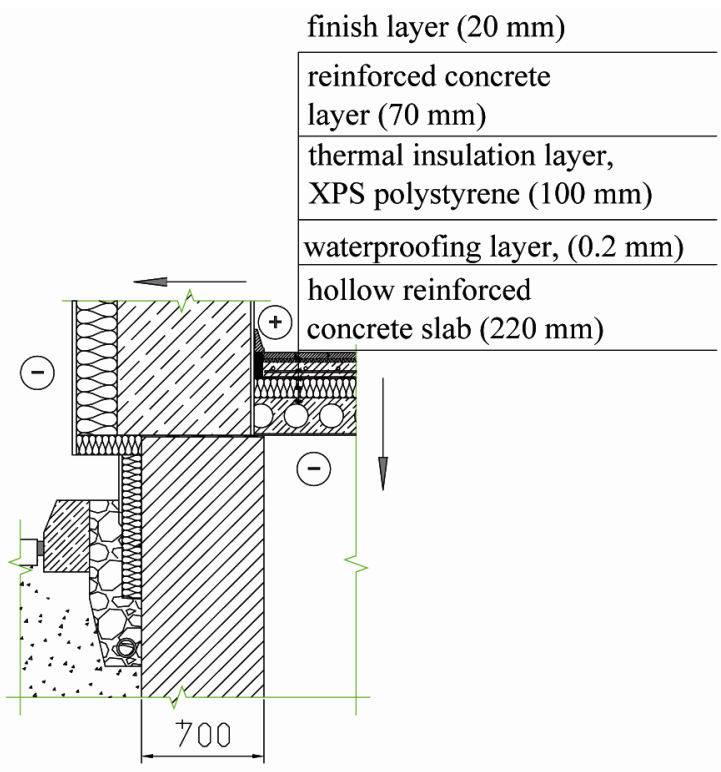

Fig. 6. Improvement of the thermal insulation layer $(100 \mathrm{~mm}$ in width) on the ceiling of the building cellar

With the help of multi-objective decision-making methods, the research aims to create a technique for an effective selection of insulation for building envelope.

\section{Multi-objective optimisation on the basis of the ratio analysis method}

Multi-objective Decision Making MODM - a simplified and less time-consuming method for mathematical investigation of comparative performance was selected (Chakraborty 2011). Multiple Objective decision methods MOORA and MULTIMOORA were selected for further calculation.

For the first time, multi-objective optimization on the basis of the ratio analysis was introduced by Brauers and Zavadskas (2006). The method starts with a matrix of responses of different alternatives to different objectives:

$$
X=\left[\begin{array}{ccccc}
x_{11} & \ldots & x_{1 i} & \ldots & x_{1 n} \\
\vdots & \ddots & \vdots & \ddots & \vdots \\
x_{j 1} & \ldots & x_{j i} & \ldots & x_{j n} \\
\vdots & \ddots & \vdots & \ddots & \vdots \\
x_{m 1} & \ldots & x_{m i} & \ldots & x_{m n}
\end{array}\right]
$$

where: $x_{i j}$ - the response of alternative $j$ on objective $i$;

$i=1,2, \ldots, n-$ the number of objectives;

$j=1,2, \ldots, m-$ the number of alternatives.

The MOORA method consists of two components: (4.1) the ratio system and (4.2) the reference point approach.

\subsection{The ratio system as a part of MOORA}

In the ratio system of MOORA, each response of an alternative to an objective is compared to a denominator, which represents all alternatives related to that objective. The square root of the sum of squares of each alternative to the objective was used as denominator in the MOORA formula (Van Delft, Nijkamp 1977):

$$
\bar{x}_{i j}=\frac{x_{i j}}{\sqrt{\sum_{j=1}^{m} x_{i j}^{2}}},
$$

with: $x_{i j}$ - response of alternative $j$ to objective $i$;

$j=1,2, \ldots, m ; m-$ the number of alternatives;

$i=1,2, \ldots, n ; n-$ the number of objectives;

$\bar{x}_{i j}$ - a dimensionless number representing the response of alternative $j$ to objective $i$.

Brauers and Zavadskas (2006) proved that this formula is the best choice between many other possible ones.

Dimensionless numbers have no specific unit of measurement. They are obtained, for instance, by deduction, multiplication or division. The normalised response of the alternatives to the objectives belongs to the interval $[0 ; 1]$. However, sometimes the interval could be $[-1 ; 1]$. Indeed, in the case of the productivity growth, some sector, region or country may show a decrease instead of an increase in productivity, i.e. a negative dimensionless number.

For optimisation, in case of maximisation these responses are added and in case of minimisation - subtracted:

$$
\bar{y}_{j}=\sum_{i=1}^{i=g} \bar{x}_{i j}-\sum_{i=g+1}^{i=n} \bar{x}_{i j},
$$

where: $i=1,2, \ldots, g-$ the objectives to be maximized;

$i=g+1, g+2, \ldots, n-$ the objectives to be minimised.

$\bar{y}_{j}$ - the normalised assessment of alternative $j$ with respect to all objectives.

An ordinal ranking of $\bar{y}_{j}$ shows the final preference. Nevertheless, it may turn out to be necessary to stress that some objectives are more important than the others. In order to give more importance to an objective, it could be multiplied by a significance coefficient. 


\subsection{The reference point approach as a part of MOORA}

The reference point theory is based on the ratios found in equation (2), whereby a maximal objective reference point is also deduced. The maximal objective reference point approach is called realistic and non-subjective when the coordinates $\left(r_{i}\right)$ selected for the reference point are realised in one of the candidate alternatives. For example, we have three alternatives described as follows: $A(10$; $100), B(100 ; 20)$ and $C(50 ; 50)$. In this case, the maximal objective reference point $R_{m}$ results in $(100 ; 100)$. The maximal objective vector is self-evident if the alternatives are well defined as for the projects in the area of project analysis and planning.

Given the dimensionless number representing the response of alternative $j$ to objective $i$, i.e. $\bar{x}_{i j}$ in equation (2), we come to:

$$
\left(r_{i}-\bar{x}_{i j}\right),
$$

where: $i=1,2, \ldots, n$ as the objective;

$j=1,2, \ldots, m$ as the alternatives;

$r_{i}-$ the $i^{\text {th }}$ coordinate of the reference point;

$\bar{x}_{i j}-$ the ratio found in the ratio system (formula 2).

This matrix is subject to the Min-Max metric of Tchebycheff (Karlin, Studden 1966):

$$
\underset{(j)}{\operatorname{Min}}\left\{\max _{(i)}\left(r_{i}-\bar{x}_{i j}\right)\right\} \text {. }
$$

The Min-Max metric is the best choice between all the possible metrics of the reference point theory (Brauers 2004: 159-161).

\subsection{The Full Multiplicative Form}

From now, in order to distinguish it from the mixed forms, the following form of $n$-power for multi-objectives is called a full-multiplicative form:

$$
U_{j}=\prod_{i=1}^{n} x_{i j}
$$

with: $j=1,2, \ldots, m ; m$ the number of alternatives;

$i=1,2, \ldots, n ; n$ being the number of objectives;

$x_{i j}$ response of alternative $j$ to objective $i$;

$U_{j}$ overall utility of alternative $j$.

The overall utilities $\left(U_{j}\right)$, obtained by multiplication of different units of measurement, become dimensionless.

The objectives to be minimised are denominators in the formula:

$$
U_{j}=\frac{A_{j}}{B_{j}},
$$

with: $A_{j}=\prod_{g=1}^{i} x_{g i}$,

$i$ the number of objectives to be maximized, with: $B_{j}=\prod_{k=i+1}^{n} x_{k i}$,

$n-i-$ the number of objectives to be minimized,

with: $U_{j}$ - the utility of alternative $j$ with objectives to be maximised and objectives to be minimised.

\section{MULTIMOORA}

MULTIMOORA is the combination of the MOORA method and of the Full Multiplicative Form of Multiple Objectives. For the first time, MULTIMOORA was introduced by Brauers and Zavadskas in the beginning of 2010 (Brauers, Zavadskas 2010a). MULTIMOORA became the most robust system of multiple optimisations under condition of support from the Ameliorated Nominal Group Technique and Delphi method (Brauers, Zavadskas 2010b, 2011 a; Brauers, Ginevicius 2010).

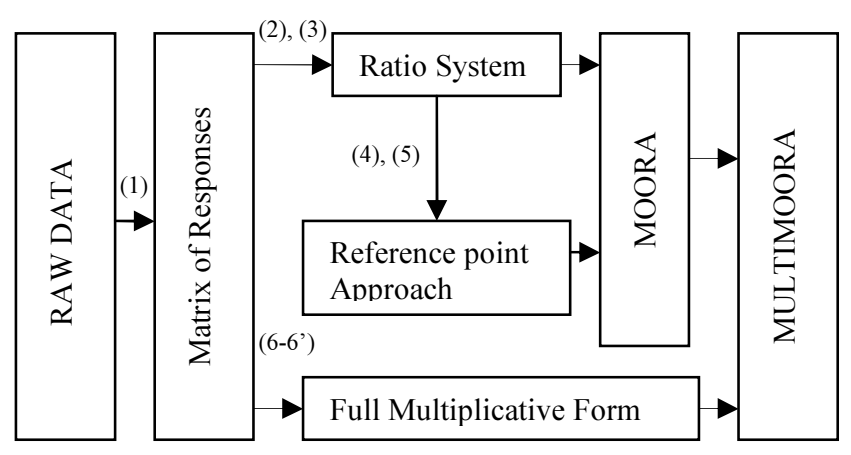

Fig. 7. Diagram of MULTIMOORA

Diagram Fig. 7 represents the combination of the three different methods of MULTIMOORA (Brauers, Zavadskas 2011b). Nominal Group Technique: 1) the Ratio System; 2) the Reference Point Approach; 3) the Full Multiplicative Form. The Nominal Group Technique and the Delphi method can also be used to reduce the remaining subjectivity. Numbers and arrows in the picture are referring by formulas rank and the priority in the multiobjective method.

\section{Effective selection of building envelope insulation alternatives using multi-objective decision-making methods}

In order to find an optimal alternative the multi-objective optimization method MOORA (Multi-Objective Optimisation by Ratio analysis) and MULTIMOORA (MOORA plus Full Multiplicative Form) were used.

When using multi-objective optimisation methods, all objectives must be measurable. Multi-objective techniques seem to be an appropriate tool for ranking or selecting one or more alternatives from a set of available options based on the multiple, sometimes conflicting objectives. A large number of methods have been developed for solving multi-objective problems (Balezentis et al. 2011; Zavadskas et al. 2010; Medineckiene et al. 2011). Multi-objective optimisation frameworks vary from simple approaches, requiring very little information, 
to methods based on mathematical programming techniques, requiring extensive information on each objective and on the preferences of the stakeholders.

Various objectives of effectiveness are proposed with different dimensions, different significances as well as different directions of optimization.

The main steps of multiple attribute decisionmaking are as follow (Kaklauskas et al. 2008; Natividade-Jesus et al. 2007):

- the system of evaluation attributes that relates system capabilities to goals;

- the alternative systems for attaining the goals (generating alternatives);

- the initial data;

- application of a multiple-objectives analysis method;

- calculation of results and selection of the "optimal" (preferred) alternative.

A case study considers 20 possible alternatives of external walls, roofs, ceilings and windows. Some alternatives given in Table 2 (wall 1, roof 1 , roof 2 , ceiling 1, windows 1) don't comply the requirements of Lithuanian standards for thermal insulation.

In alternatives windows 2 and windows 4 it was decided to change windows only on the northern side, in total around $258.30 \mathrm{~m}^{2}$.

Each alternative provided in Table 2, is described by seven objectives: $\mathbf{x}_{1}-$ Thermal resistance $\left[\mathrm{W} / \mathrm{K} \cdot \mathrm{m}^{2}\right]$;

$\mathbf{x}_{2}-$ Partition price per square meter $\left[€ / \mathrm{m}^{2}\right]$;

$\mathbf{x}_{\mathbf{3}}$ - Total partition price [EUR]; EUR 1= LTL 3.458;

$\mathbf{x}_{4}-$ Counted partition heat losses $\left[\mathrm{kWh} / \mathrm{m}^{2}\right.$ per year $]$;

$\mathbf{x}_{5}$ - Savings in the amount of heat loss $\left[\mathrm{kWh} / \mathrm{m}^{2} \cdot\right.$ year $]$;

$\mathbf{x}_{\mathbf{6}}-$ Total amount saved per year [EUR/year];

$\mathbf{x}_{7}-$ Simple payback period [year].

The main purpose of a residential building is to create good living conditions with appropriate air ventilation, level of humidity and heating (Sobotka, Rolak 2009; Thomas 2010). The basic design of a building must comply with certain requirements. External walls, roof, ground storey, doors and windows have a particular role in the construction of a building. These elements can influence the choice of heating and cooling systems used depending on the season. Only comprehensive assessment of elements that are responsible for heat losses can greatly reduce related costs, especially in renovated buildings (Juodis et al. 2009; Ginevicius et al. 2008).

The effective selection of walls with the help of calculations applied in the multiple objective methods are described in Tables 3 and 4. Calculations pertaining to other partitions are provided in annexes $\mathrm{A}, \mathrm{B}$ and $\mathrm{C}$.

Objectives that define heat losses, payback period and partition renovation prices are minimised; whereas heat resistance and heat savings subsequent to renovation of the building are maximized.

Table 2. Heating energy consumptions, costs and payback periods of the main partitions

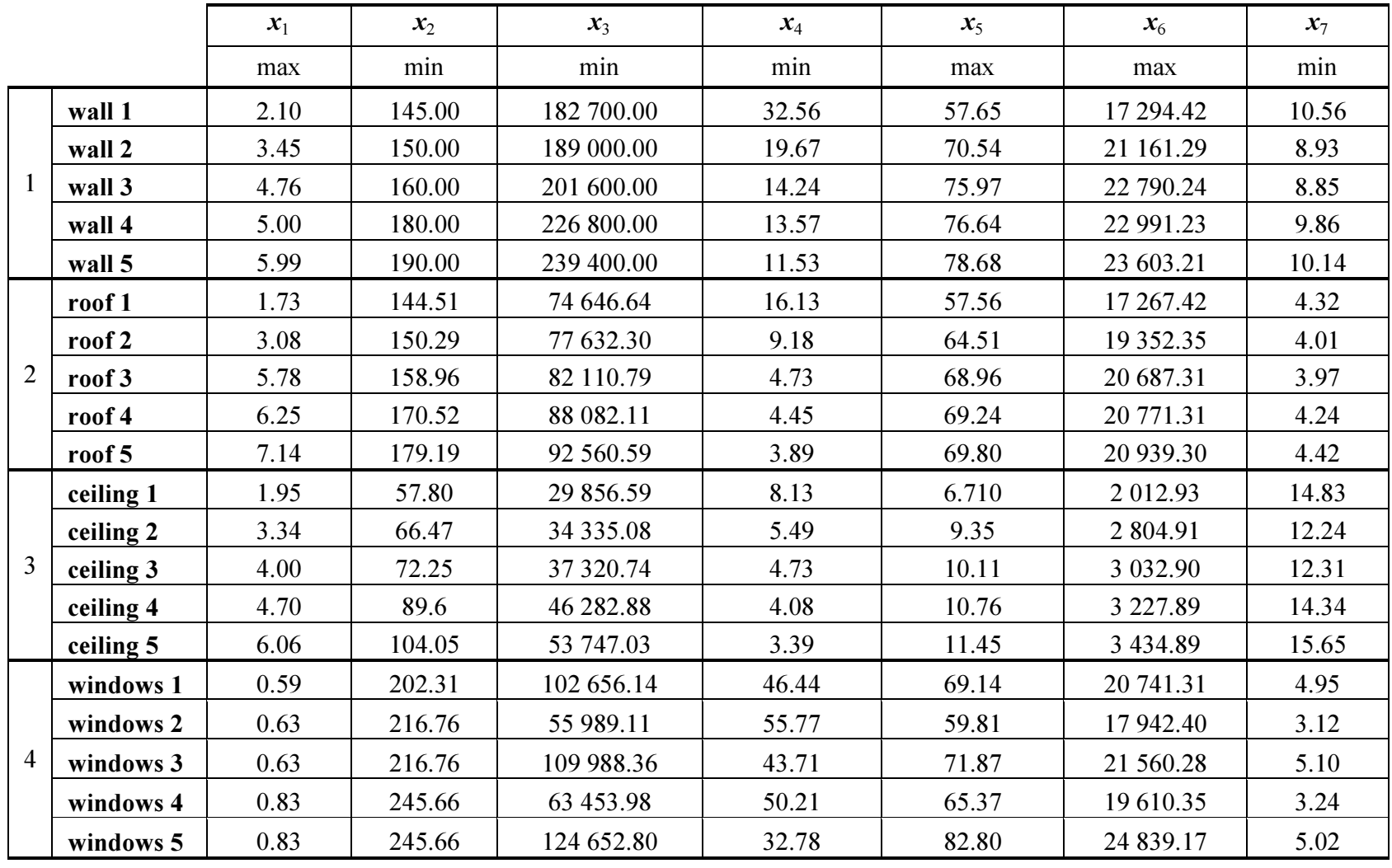


Table 3. MOORA applied on 5 wall alternatives with 7 conditions

3a. Matrix of responses of alternatives on objectives: $\left(x_{i j}\right)$

\begin{tabular}{|cccccccc|}
\hline & $\boldsymbol{x}_{1}$ & $\boldsymbol{x}_{2}$ & $\boldsymbol{x}_{3}$ & $x_{4}$ & $\boldsymbol{x}_{5}$ & $\boldsymbol{x}_{6}$ & $\boldsymbol{x}_{7}$ \\
\cline { 2 - 7 } & $\max$ & $\min$ & $\min$ & $\min$ & $\max$ & $\max$ & 17294.42 \\
\hline wall 1 & 2.10 & 145 & 182700.00 & 32.56 & 57.65 & 10.56 \\
\hline wall 2 & 3.45 & 150 & 189000.00 & 19.67 & 70.54 & 21161.29 & 8.93 \\
\hline wall 3 & 4.76 & 160 & 201600.00 & 14.24 & 75.97 & 22790.24 & 8.85 \\
\hline wall 4 & 5.00 & 180 & 226800.00 & 13.57 & 76.64 & 22991.23 & 9.86 \\
\hline wall 5 & 5.99 & 190 & 239400.00 & 11.53 & 78.68 & 23603.21 & 10.14 \\
\hline
\end{tabular}

3b. Sum of squares and their square roots

\begin{tabular}{|crrrrrrr|}
\hline & \multicolumn{1}{c}{$\boldsymbol{x}_{1}$} & \multicolumn{1}{c}{$\boldsymbol{x}_{2}$} & \multicolumn{1}{c}{$\boldsymbol{x}_{3}$} & \multicolumn{1}{c}{$\boldsymbol{x}_{4}$} & \multicolumn{1}{c}{$\boldsymbol{x}_{5}$} & \multicolumn{1}{c}{$\boldsymbol{x}_{6}$} & \multicolumn{1}{c}{$\boldsymbol{x}_{7}$} \\
\hline wall 1 & 4.41 & 21025 & $33379.29 \cdot 10^{6}$ & 1060.15 & 3323.52 & $2990.97 \cdot 10^{5}$ & 111.60 \\
\hline wall 2 & 11.89 & 22500 & $35721 \cdot 10^{6}$ & 386.91 & 4975.89 & $4478.00 \cdot 10^{5}$ & 79.77 \\
\hline wall 3 & 22.68 & 25600 & $40642.56 \cdot 10^{6}$ & 202.78 & 5771.44 & $5193.950 \cdot 10^{5}$ & 78.25 \\
\hline wall 4 & 25.00 & 32400 & $51438.24 \cdot 10^{6}$ & 184.15 & 5873.69 & $5285.96 \cdot 10^{5}$ & 97.31 \\
\hline wall 5 & 35.86 & 36100 & $57312.36 \cdot 10^{6}$ & 132.94 & 6190.54 & $5571.11 \cdot 10^{5}$ & 102.87 \\
\hline Sum of squares. & 99.84 & 137625.00 & $218493450 \cdot 10^{6}$ & 1966.93 & 26135.09 & $23520.01 \cdot 10^{5}$ & 469.81 \\
\hline Square roots & 9.99 & 370.98 & 467432.82 & 44.35 & 161.66 & 48497.43 & 21.68 \\
\hline
\end{tabular}

3c. Objectives divided by their square roots and MOORA

\begin{tabular}{|clllllll|rr|}
\hline & $\boldsymbol{x}_{1}$ & $\boldsymbol{x}_{2}$ & $\boldsymbol{x}_{3}$ & $\boldsymbol{x}_{4}$ & $\boldsymbol{x}_{5}$ & $\boldsymbol{x}_{6}$ & $\boldsymbol{x}_{7}$ & total & Rank max \\
\hline wall 1 & 0.210 & 0.391 & 0.391 & 0.734 & 0.357 & 0.357 & 0.487 & -1.080 & $\mathbf{5}$ \\
\hline wall 2 & 0.345 & 0.404 & 0.404 & 0.444 & 0.436 & 0.436 & 0.412 & -0.446 & $\mathbf{4}$ \\
\hline wall 3 & 0.477 & 0.431 & 0.431 & 0.321 & 0.470 & 0.470 & 0.408 & -0.175 & $\mathbf{1}$ \\
\hline wall 4 & 0.500 & 0.485 & 0.485 & 0.306 & 0.474 & 0.474 & 0.455 & -0.283 & $\mathbf{3}$ \\
\hline wall 5 & 0.599 & 0.512 & 0.512 & 0.260 & 0.487 & 0.487 & 0.468 & -0.180 & $\mathbf{2}$ \\
\hline
\end{tabular}

$3 \mathrm{~d}$. Reference point theory with ratios: coordinates of the reference point equal to the maximal objective values

\begin{tabular}{ccccccccc}
\hline & $\boldsymbol{x}_{1}$ & $\boldsymbol{x}_{2}$ & $\boldsymbol{x}_{3}$ & $\boldsymbol{x}_{4}$ & $\boldsymbol{x}_{5}$ & $\boldsymbol{x}_{7}$ & & \\
\hline $\boldsymbol{r}_{\boldsymbol{i}}$ & 0.599 & 0.391 & 0.391 & 0.260 & 0.487 & 0.487 & 0.408 & 0.487 \\
\hline
\end{tabular}

3e. Reference point theory: deviations from the reference point

\begin{tabular}{|cccccccc:ccc|}
\hline & $\boldsymbol{x}_{1}$ & $\boldsymbol{x}_{2}$ & $\boldsymbol{x}_{3}$ & $\boldsymbol{x}_{4}$ & $\boldsymbol{x}_{5}$ & $\boldsymbol{x}_{6}$ & $\boldsymbol{x}_{7}$ & $\max$ & Rank min \\
\hline wall 1 & 0.389 & 0.000 & 0.000 & 0.474 & 0.130 & 0.130 & 0.079 & 0.474 & $\mathbf{5}$ \\
\hline wall 2 & 0.254 & 0.013 & 0.013 & 0.184 & 0.050 & 0.050 & 0.004 & 0.254 \\
\hline wall 3 & 0.123 & 0.040 & 0.040 & 0.061 & 0.017 & 0.017 & 0.000 & 0.123 \\
\hline wall 4 & 0.099 & 0.094 & 0.094 & 0.046 & 0.013 & 0.013 & 0.047 & 0.099 & $\mathbf{3}$ \\
\hline wall 5 & 0.000 & 0.121 & 0.121 & 0.000 & 0.000 & 0.000 & 0.060 & 0.121 \\
\hline
\end{tabular}

Table 4. The Full Multiplicative Form

\begin{tabular}{|ccccccccccc}
\hline & $\mathrm{A}$ & $\mathrm{B}$ & $\mathrm{C}$ & $\mathrm{D}$ & $\mathrm{E}$ & $\mathrm{F}$ & $\mathrm{G}$ & $\mathrm{H}$ & $\mathrm{I}$ \\
& $\max$ & $\min$ & $\mathrm{C}=\mathrm{A}: \mathrm{B}$ & $\min$ & $\mathrm{E}=\mathrm{C}: \mathrm{D}$ & $\min$ & $\mathrm{G}=\mathrm{E}: \mathrm{F}$ & $\max$ & $\mathrm{I}=\mathrm{G} \cdot \mathrm{H}$ \\
\hline wall 1 & 2.10 & 145 & 0.01 & 182700.00 & $7.93 \cdot 10^{-8}$ & 32.56 & $2.44 \cdot 10^{-9}$ & 57.65 & $1.4 \cdot 10^{-7}$ \\
\hline wall 2 & 3.45 & 150 & 0.02 & 189000.00 & $1.21 \cdot 10^{-7}$ & 19.67 & $6.18 \cdot 10^{-9}$ & 70.54 & $4.36 \cdot 10^{-7}$ \\
\hline wall 3 & 4.76 & 160 & 0.03 & 201600.00 & $1.47 \cdot 10^{-7}$ & 14.24 & $1.04 \cdot 10^{-8}$ & 75.97 & $7.88 \cdot 10^{-7}$ \\
\hline wall 4 & 5.00 & 180 & 0.03 & 226800.00 & $1.22 \cdot 10^{-7}$ & 13.57 & $9.02 \cdot 10^{-9}$ & 76.64 & $6.92 \cdot 10^{-7}$ \\
\hline wall 5 & 5.99 & 190 & 0.03 & 239400.00 & $1.31 \cdot 10^{-7}$ & 11.53 & $1.14 \cdot 10^{-8}$ & 78.68 & $8.98 \cdot 10^{-7}$ \\
\hline
\end{tabular}

\begin{tabular}{cccccc}
\hline $\mathrm{J}$ & $\mathrm{K}$ & $\mathrm{L}$ & $\mathrm{M}$ & \multirow{2}{*}{ Result } & \multirow{2}{*}{ Project } \\
\cline { 1 - 4 } $\max$ & $\mathrm{K}=\mathrm{I} \cdot \mathrm{J}$ & $\min$ & $\mathrm{M}=\mathrm{K}: \mathrm{L}$ & & \\
\hline 17294.42 & $0.24 \cdot 10^{-2}$ & 10.56 & $0.23 \cdot 10^{-3}$ & 5 & wall 1 \\
\hline 21161.29 & $0.92 \cdot 10^{-2}$ & 8.93 & $1.03 \cdot 10^{-3}$ & 4 & wall 2 \\
\hline 22790.24 & $1.79 \cdot 10^{-2}$ & 8.85 & $2.03 \cdot 10^{-3}$ & 2 & wall 3 \\
\hline 22991.23 & $1.59 \cdot 10^{-2}$ & 9.86 & $1.61 \cdot 10^{-3}$ & 3 & wall 4 \\
\hline 23603.21 & $2.12 \cdot 10^{-2}$ & 10.14 & $2.09 \cdot 10^{-3}$ & 1 & wall 5 \\
\hline
\end{tabular}


Table 5. MULTIMOORA as a consequence of the MOORA method and of the Full Multiplicative Form

\begin{tabular}{|c|c|c|c|c|c|}
\hline & \multicolumn{2}{|c|}{ MOORA } & \multirow{2}{*}{ Full Multiplicative Form } & \multirow{2}{*}{$\begin{array}{c}\text { MULTIMOORA } \\
\text { Rank }\end{array}$} \\
\hline & & Ratio system & Reference point & & \\
\hline \multirow{5}{*}{1} & wall 1 & 5 & 5 & 5 & 5 \\
\hline & wall 2 & 4 & 4 & 4 & 4 \\
\hline & wall 3 & 1 & 3 & 2 & 2 \\
\hline & wall 4 & 3 & 1 & 3 & 3 \\
\hline & wall 5 & 2 & 2 & 1 & 1 \\
\hline \multirow{5}{*}{2} & roof 1 & 5 & 5 & 5 & 5 \\
\hline & roof 2 & 4 & 4 & 4 & 4 \\
\hline & roof 3 & 2 & 3 & 2 & 2 \\
\hline & roof 4 & 3 & 1 & 3 & 3 \\
\hline & roof 5 & 1 & 2 & 1 & 1 \\
\hline \multirow{5}{*}{3} & ceiling 1 & 5 & 5 & 5 & 5 \\
\hline & ceiling 2 & 4 & 4 & 4 & 4 \\
\hline & ceiling 3 & 2 & 2 & 2 & 2 \\
\hline & ceiling 4 & 3 & 1 & 3 & 3 \\
\hline & ceiling 5 & 1 & 3 & 1 & 1 \\
\hline \multirow{5}{*}{4} & windows 1 & 5 & 2 & 5 & 5 \\
\hline & windows 2 & 3 & 3 & 3 & 3 \\
\hline & windows 3 & 4 & 4 & 4 & 4 \\
\hline & windows 4 & 1 & 1 & 1 & 1 \\
\hline & windows 5 & 2 & 5 & 2 & 2 \\
\hline
\end{tabular}

\section{Calculation results}

MULTIMOORA optimisation techniques with discrete dimensionless measures were used for ranking alternatives in this study. Three results were obtained. Indeed MOORA consists of two components: the ratio system and the reference point, whereas MULTIMOORA adds the Full Multiplicative Form: Table 5 represents the final outcomes.

MULTIMOORA optimised the best thermal insulation variant for renovation of a building structure: wall number 5 , roof number 5 , ceiling number 5 and window number 4 .

Instead of the insulation problem for buildings from the Soviet period in Lithuania, a much heavier problem of Multi-Objective Decision Making will arrive when the economic depreciation of the Soviet time buildings will come to its end. At that moment, with an exception for the historical buildings, the following alternative choice will arrive. On the one hand, the keeping in operation of the Soviet time buildings with huge maintenance costs or on the other hand new constructions with lower maintenance costs, better and cheaper material, such as the replacement of wet construction by dry construction, lower labour costs and more modern comfort but with a new starting economic depreciation.

\section{Conclusions}

One of the most difficult tasks, during the building audit is ensuring a proper design of thermal insulation for building envelope. The method presented in this article, called MULTIMOORA, optimises building envelope improvements concerning insulation. This method can facilitate and accelerate selection of insulation for building envelope on the basis of local technical specifications.
Inside MULTIMOORA three methods are assumed to have the same importance. These three methods represent all existing methods with dimensionless measures in multi-objective optimisation. With the help of these Multi-Objective Optimisation methods, the case study focuses on an effective selection between 20 alternatives of building partitions. Five renovation scenarios based on small (alternatives 1), medium (alternative 2 to alternatives 3) and basic (alternative 4 to alternatives 5) investment packages were proposed for residential multiapartment buildings in Lithuania and the priority order for their application was determined.

MULTIMOORA optimised the best thermal insulation variant for renovation of a building structure concerning walls, roof, ceiling and windows.

With the help of MULTIMOORA, this study proved that the proposed theoretical model was effective in real life and could be successfully applied for a solution of similar utility problems in construction as well as in other fields

\section{References}

Balezentis, T.; Balezentis, A.; Brauers, W. K. M. 2011. Multiobjective optimization of well-being in the European Union member states, Ekonomska Istrazivanja - Economic Research 24(4): 1-15.

Brauers, W. K. M.; Ginevicius, R. 2010. The economy of the Belgian regions tested with MULTIMOORA, Journal of Business Economics and Management 11(2): 173-209. http://dx.doi.org/10.3846/jbem.2010.09

Brauers, W. K. M.; Zavadskas, E. K. 2006. The MOORA method and its application to privatization in a transition economy, Control and Cybernetics 35(2): 445-469. 
Brauers, W. K. M.; Zavadskas, E. K. 2010a. Robustness in the MULTIMOORA model: the example of Tanzania, Transformations in Business \& Economics 9(3): 67-83.

Brauers, W. K. M.; Zavadskas, E. K. 2010b. Project management by MULTIMOOORA as an instrument for transition economies, Technological and Economic Development of Economy 16(1): 5-24.

http://dx.doi.org/10.3846/tede.2010.01

Brauers, W. K. M.; Zavadskas, E. K. 2011a. From a centrally planned economy to multi-objective optimization in an enlarged project management the case of China, Economic Computation and Economic Cybernetics Studies and Research 45(1): 167-187.

Brauers, W. K. M.; Zavadskas, E. K. 2011 b. MULTIMOORA optimization used to decide on a bank loan to buy property, Technological and Economic Development of Economy 17(1): 174-188.

http://dx.doi.org/10.3846/13928619.2011.560632

Brauers, W. K. 2004. Optimization Methods for a Stakeholder Society, a Revolution in Economic Thinking by MultiObjective Optimization, Series: Nonconvex Optimization and its Applications, Volume 73, Kluwer Academic Publishers and Springer, Boston-Dordrecht-London. 342 p.

Chakraborty, S. 2011. Applications of the MOORA method for decision making in manufacturing environment, International Journal of Advanced Manufacturing Technology 54(9-12): 1155-1166. http://dx.doi.org/10.1007/s00170010-2972-0

Davies, P.; Osmani, M. 2011. Low carbon housing refurbishment challenges and incentives: Architects' perspectives, Building and Environment 46(8): 1691-1698. http://dx.doi.org/10.1016/j.buildenv.2011.02.011

European Commission, 2011. Directive of the European parliament and of the council on energy efficiency and repealing Directives 2006/32/EC.2011 and 2006/32/EC. Available from Internet: http://ec.europa.eu.

Flores-Colen, I.; de Brito, J. 2010. A systematic approach for maintenance budgeting of buildings facades based on predictive and preventive strategies, Construction and Building Materialss 24(9): 1718-1729.

http://dx.doi.org/10.1016/j.conbuildmat.2010.02.017

Ginevicius, R.; Podvezko, V.; Raslanas, S. 2008. Evaluating the alternative solutions of wall insulation by multicriteria methods, Journal of Civil Engineering and Management 14(4): 217-226.

http://dx.doi.org/10.3846/1392-3730.2008.14.20

Golic, K.; Kosoric, V.; Furundzic, A. K. 2011. General model of solar water heating system integration in residential building refurbishment - Potential energy savings and environmental impact, Renewable and Sustainable Energy Reviews 15(3): 1533-1544.

Huang, C. F.; Hsueh, S. L. 2010. Customer behavior and decision making in the refurbishment industry - a data mining approach, Journal of Civil Engineering and Management 16(1): 75-84. http://dx.doi.org/10.3846/jcem.2010.07

Juodis, E.; Jaraminiene, E.; Dudkiewicz, E. 2009. Inherent variability of heat consumption in residential buildings, Energy and Buildings 41(11): 1188-1194. http://dx.doi.org/10.1016/j.enbuild.2009.06.007
Kaklauskas, A.; Rute, J.; Gudauskas, R.; Banaitis, A. 2011. Integrated model and system for passive houses multiple criteria analysis, International Journal of Strategic Property Management 15(1): 74-90. http://dx.doi.org/10.3846/1648715X.2011.574903

Kaklauskas, A.; Zavadskas, E. K.; Galiniene, B. 2008. A building's refurbishment knowledge-based decision support system, International Journal of Environment and Pollution 35(2-4): 237-249. http://dx.doi.org/10.1504/IJEP.2008.021358

Kalibatas, D.; Zavadskas, E. K.; Kalibatiene, D. 2011. The concept of the ideal indoor environment in multi-attribute assessment of dwelling-houses, Archives of Civil Mechanical Engineering 11(1): 89-101.

Karlin, S.; Studden, W. J. 1966. Tchebycheff Systems: with Applications in Analysis and Statistics. Interscience Publishers, New York. 568 p.

Medineckiene, M.; Zavadskas, E. K.; Turskis, Z. 2011. Dwelling selection by applying fuzzy game theory, Archives of Civil and Mechanical Engineering 11(3): 681-697. http://dx.doi.org/10.1016/S1644-9665(12)60109-5

Motuziene, V.; Juodis, E. S. 2010. Simulation based complex energy assessment of office building fenestration, Journal of Civil Engineering and Management 16(3): 345351. http://dx.doi.org/10.3846/jcem.2010.39

Natividade-Jesus, E.; Coutinho-Rodrigues, J.; Antunes, C. H. 2007. A multicriteria decision support system for housing evaluation, Decision Support Systems 43(3): 779-790. http://dx.doi.org/10.1016/j.dss.2006.03.014

Pasanisi, A.; Ojalvo, J. 2008. A multi-criteria decision tool to improve the energy efficiency of residential buildings, Foundations of Computing and Decision Sciences 33(1): 71-82.

Sobotka, A.; Rolak, Z. 2009. Multi-attribute analysis for the eco-energetic assessment of the building life cycle, Technological and Economic Development of Economy 15(4): 593-611. http://dx.doi.org/10.3846/1392-8619.2009.15.593-611

STR.1.12.06:2002. Building usage and lifetime. Construction technical regulation. Lithuania, 2002.

STR.2.05.01:2005. Thermal Technique of the Building Envelope. Construction technical regulation. Lithuania, 2005.

Thomas, L. E. 2010. Evaluating design strategies, performance and occupant satisfaction: a low carbon office refurbishment, Building Research and Information 38(6): 610-624. http://dx.doi.org/10.1080/09613218.2010.501654

Tupenaite, L.; Zavadskas, E. K.; Kaklauskas, A.; Turskis, Z.; Seniut, M. 2010. Multiple criteria assessment of alternatives for built and human environment renovation, Journal of Civil Engineering and Management 16(2): 257-266. http://dx.doi.org/10.3846/jcem.2010.30

Van Delf, A.; Nijkamp, P. 1977. Multi-criteria Analysis and Regional Decision-making. Leiden: Martinus Nijhoff Social Sciences Division. $135 \mathrm{p}$.

Zavadskas, E. K.; Turskis, Z.; Vilutiene, T. 2010. Multiple criteria analysis of foundation instalment alternatives by applying Additive Ratio Assessment (ARAS) method, Archives of Civil and Mechanical Engineering 10(3): 123141. http://dx.doi.org/10.1016/S1644-9665(12)60141-1 


\section{Annex A}

Table 6. MOORA applied on 5 roof alternatives with 7 conditions

6a. Matrix of responses of alternatives on objectives: $\left(x_{i j}\right)$

\begin{tabular}{|cccccccc|}
\hline & $\boldsymbol{x}_{1}$ & $\boldsymbol{x}_{2}$ & $\boldsymbol{x}_{3}$ & $\boldsymbol{x}_{4}$ & $\boldsymbol{x}_{5}$ & $\boldsymbol{x}_{6}$ & $\boldsymbol{x}_{7}$ \\
\cline { 2 - 7 } & $\max$ & $\min$ & $\min$ & $\min$ & $\max$ & $\max$ \\
\hline roof 1 & 1.73 & 144.51 & 74646.64 & 16.13 & 57.56 & 17267.42 & 4.32 \\
\hline roof 2 & 3.08 & 150.29 & 77632.30 & 9.18 & 64.51 & 19352.35 & 4.01 \\
\hline roof 3 & 5.78 & 158.96 & 82110.79 & 4.73 & 68.96 & 20687.31 & 3.97 \\
\hline roof 4 & 6.25 & 170.52 & 88082.11 & 4.45 & 69.24 & 20771.31 & 4.24 \\
\hline roof 5 & 7.14 & 179.19 & 92560.59 & 3.89 & 69.80 & 20939.30 & 4.42 \\
\hline
\end{tabular}

6b. Sum of squares and their square roots

\begin{tabular}{|crrrrrrr|}
\hline & \multicolumn{1}{c}{$\boldsymbol{x}_{1}$} & \multicolumn{1}{c}{$\boldsymbol{x}_{2}$} & \multicolumn{1}{c}{$\boldsymbol{x}_{3}$} & \multicolumn{1}{c}{$\boldsymbol{x}_{4}$} & \multicolumn{1}{c}{$\boldsymbol{x}_{5}$} & $\boldsymbol{x}_{6}$ & $\boldsymbol{x}_{7}$ \\
\hline roof 1 & 2.98 & 20883.14 & $5572.12 \cdot 10^{6}$ & 260.18 & 3313.15 & $298.16 \cdot 10^{6}$ & 18.69 \\
\hline roof 2 & 9.48 & 22587.08 & $6026.77 \cdot 10^{6}$ & 84.27 & 4161.54 & $374.51 \cdot 10^{6}$ & 16.09 \\
\hline roof 3 & 33.41 & 25268.28 & $6742.18 \cdot 10^{6}$ & 22.37 & 4755.48 & $427.96 \cdot 10^{6}$ & 15.75 \\
\hline roof 4 & 39.06 & 29077.07 & $7758.45 \cdot 10^{6}$ & 19.80 & 4794.18 & $431.45 \cdot 10^{6}$ & 17.98 \\
\hline roof 5 & 51.02 & 32109.06 & $8567.46 \cdot 10^{6}$ & 15.13 & 4872.04 & $438.45 \cdot 10^{6}$ & 19.54 \\
\hline Sum of squares. & 135.95 & 129924.63 & $34666.99 \cdot 10^{6}$ & 401.76 & 21896.39 & $1970.54 \cdot 10^{6}$ & 88.06 \\
\hline Square roots & 11.66 & 360.45 & 186190.755 & 20.044 & 147.974 & 44390.81 & 9.38 \\
\hline
\end{tabular}

6c. Objectives divided by their square roots and MOORA

\begin{tabular}{|lccccccc|cc|c|}
\hline & $\boldsymbol{x}_{1}$ & $\boldsymbol{x}_{2}$ & $\boldsymbol{x}_{3}$ & $\boldsymbol{x}_{4}$ & $\boldsymbol{x}_{5}$ & $\boldsymbol{x}_{6}$ & $\boldsymbol{x}_{7}$ & total & rank \\
\hline roof 1 & 0.148 & 0.401 & 0.401 & 0.805 & 0.389 & 0.389 & 0.461 & -1.141 & $\mathbf{5}$ \\
\hline roof 2 & 0.264 & 0.417 & 0.417 & 0.458 & 0.436 & 0.436 & 0.427 & -0.584 & $\mathbf{4}$ \\
\hline roof 3 & 0.496 & 0.441 & 0.441 & 0.236 & 0.466 & 0.466 & 0.423 & -0.113 & $\mathbf{2}$ \\
\hline roof 4 & 0.536 & 0.473 & 0.473 & 0.222 & 0.468 & 0.468 & 0.452 & -0.148 & $\mathbf{3}$ \\
\hline roof 5 & 0.613 & 0.497 & 0.497 & 0.194 & 0.472 & 0.472 & 0.471 & -0.103 \\
\hline
\end{tabular}

6d. Reference point theory with ratios: coordinates of the reference point equal to the maximal objective values

\begin{tabular}{cccccccc}
\hline & $\boldsymbol{x}_{1}$ & $\boldsymbol{x}_{2}$ & $\boldsymbol{x}_{3}$ & $\boldsymbol{x}_{4}$ & $\boldsymbol{x}_{5}$ & $\boldsymbol{x}_{6}$ & $\boldsymbol{x}_{7}$ \\
\hline $\boldsymbol{r}_{\boldsymbol{i}}$ & 0.613 & 0.401 & 0.401 & 0.194 & 0.472 & 0.472 & 0.423 \\
\hline
\end{tabular}

6e. Reference point theory: deviations from the reference point

\begin{tabular}{|rccccccc|r|r|r|}
\hline & $\boldsymbol{x}_{1}$ & $\boldsymbol{x}_{2}$ & $\boldsymbol{x}_{3}$ & $\boldsymbol{x}_{4}$ & $\boldsymbol{x}_{5}$ & $\boldsymbol{x}_{6}$ & $\boldsymbol{x}_{7}$ & $\max$ & Rank min \\
\hline roof 1 & 0.464 & 0.000 & 0.000 & 0.611 & 0.083 & 0.083 & 0.038 & 0.611 & $\mathbf{5}$ \\
\hline roof 2 & 0.349 & 0.016 & 0.016 & 0.264 & 0.036 & 0.036 & 0.005 & 0.349 & $\mathbf{4}$ \\
\hline roof 3 & 0.117 & 0.040 & 0.040 & 0.042 & 0.006 & 0.006 & 0.000 & 0.117 & $\mathbf{3}$ \\
\hline roof 4 & 0.077 & 0.072 & 0.072 & 0.028 & 0.004 & 0.004 & 0.029 & 0.0766 & $\mathbf{1}$ \\
\hline roof 5 & 0.000 & 0.096 & 0.096 & 0.000 & 0.000 & 0.000 & 0.048 & 0.096 & $\mathbf{2}$ \\
\hline
\end{tabular}

Table 6'. The full Multiplicative Form

\begin{tabular}{|cccccccccc}
\hline & $\mathrm{A}$ & $\mathrm{B}$ & $\mathrm{C}$ & $\mathrm{D}$ & $\mathrm{E}$ & $\mathrm{F}$ & $\mathrm{G}$ & $\mathrm{H}$ & $\mathrm{I}$ \\
\cline { 2 - 10 } & $\max$ & $\min$ & $\mathrm{C}=\mathrm{A}: \mathrm{B}$ & $\min$ & $\mathrm{E}=\mathrm{C}: \mathrm{D}$ & $\min$ & $\mathrm{G}=\mathrm{E}: \mathrm{F}$ & $\max$ & $\mathrm{I}=\mathrm{G} \cdot \mathrm{H}$ \\
\hline roof 1 & 1.73 & 144.51 & 0.012 & $74^{\prime} 646.64$ & $1.6011 \cdot 10^{-7}$ & 16.13 & $9.926 \cdot 10^{-9}$ & 57.56 & $5.71 \cdot 10^{-7}$ \\
\hline roof 2 & 3.08 & 150.29 & 0.021 & $77^{\prime} 632.30$ & $2.6372 \cdot 10^{-7}$ & 9.18 & $2.872 \cdot 10^{-8}$ & 64.51 & $1.85 \cdot 10^{-6}$ \\
\hline roof 3 & 5.78 & 158.96 & 0.036 & $82^{\prime} 110.79$ & $4.4286 \cdot 10^{-7}$ & 4.73 & $9.362 \cdot 10^{-8}$ & 68.96 & $6.46 \cdot 10^{-6}$ \\
\hline roof 4 & 6.25 & 170.52 & 0.037 & $88^{\prime} 082.11$ & $4.1612 \cdot 10^{-7}$ & 4.45 & $9.351 \cdot 10^{-8}$ & 69.24 & $6.47 \cdot 10^{-6}$ \\
\hline roof 5 & 7.14 & 179.19 & 0.040 & $92^{\prime} 560.59$ & $4.3066 \cdot 10^{-7}$ & 3.89 & $1.107 \cdot 10^{-7}$ & 69.80 & $7.73 \cdot 10^{-6}$ \\
\hline
\end{tabular}

\begin{tabular}{cccccc}
\hline \multicolumn{1}{c}{$\mathrm{J}$} & $\mathrm{K}$ & $\mathrm{L}$ & $\mathrm{M}$ & \multirow{2}{*}{ Result } & \multirow{2}{*}{ Project } \\
\hline $\max$ & $\mathrm{K}=\mathrm{I} \cdot \mathrm{J}$ & $\min$ & $\mathrm{M}=\mathrm{K}: \mathrm{L}$ & & \\
\hline 17267.42 & $0.99 \cdot 10^{-2}$ & 4.32 & $2.30 \cdot 10^{-3}$ & $\mathbf{5}$ & roof 1 \\
\hline 19352.35 & $3.59 \cdot 10^{-2}$ & 4.01 & $8.90 \cdot 10^{-3}$ & $\mathbf{4}$ & roof 2 \\
\hline 20687.31 & $13.36 \cdot 10^{-2}$ & 3.97 & $33.70 \cdot 10^{-3}$ & $\mathbf{2}$ & roof 3 \\
\hline 20771.31 & $13.45 \cdot 10^{-2}$ & 4.24 & $31.70 \cdot 10^{-3}$ & $\mathbf{3}$ & roof 4 \\
\hline 20939.30 & $16.18 \cdot 10^{-2}$ & 4.42 & $36.60 \cdot 10^{-3}$ & $\mathbf{1}$ & roof 5 \\
\hline
\end{tabular}




\section{Annex B}

Table 7. MOORA applied on 5 ceiling alternatives with 7 conditions

7a. Matrix of responses of alternatives on objectives: $\left(x_{i j}\right)$

\begin{tabular}{|c|c|c|c|c|c|c|c|}
\hline & $x_{1}$ & $x_{2}$ & $x_{3}$ & $x_{4}$ & $x_{5}$ & $x_{6}$ & $x_{7}$ \\
\hline & $\max$ & $\min$ & $\min$ & $\min$ & $\max$ & $\max$ & $\min$ \\
\hline ceiling 1 & 1.95 & 57.80 & 29856.59 & 8.13 & 6.71 & 2012.93 & 14.83 \\
\hline ceiling 2 & 3.34 & 65.00 & 33575.75 & 5.49 & 9.35 & 2804.91 & 11.97 \\
\hline ceiling 3 & 4.00 & 75.00 & $38 \quad 741.25$ & 4.73 & 10.11 & 3032.90 & 12.77 \\
\hline ceiling 4 & 4.700 & 90.00 & $46 \quad 489.50$ & 4.08 & 10.76 & 3227.89 & 14.40 \\
\hline ceiling 5 & 6.061 & 104.05 & $53 \quad 747.03$ & 3.39 & 11.45 & 3434.89 & 15.65 \\
\hline
\end{tabular}

7b. Sum of squares and their square roots

\begin{tabular}{|c|c|c|c|c|c|c|c|}
\hline & $x_{1}$ & $x_{2}$ & $x_{3}$ & $x_{4}$ & $x_{5}$ & $x_{6}$ & $x_{7}$ \\
\hline ceiling 1 & 3.82 & 3340.84 & $891.42 \cdot 10^{6}$ & 66.097 & 45.02 & 4051898.86 & 220.00 \\
\hline ceiling 2 & 11.19 & 4225.00 & $1127.33 \cdot 10^{6}$ & 30.140 & 87.42 & 7867500.47 & 143.29 \\
\hline ceiling 3 & 16.00 & 5625.00 & $1500.88 \cdot 10^{6}$ & 22.373 & 102.21 & 9198475.74 & 163.17 \\
\hline ceiling 4 & 22.04 & 8100.00 & $2161.27 \cdot 10^{6}$ & 16.646 & 115.78 & 10419289.35 & 207.43 \\
\hline ceiling 5 & 36.73 & 10826.40 & $2888.74 \cdot 10^{6}$ & 11.492 & 131.10 & 11798438.40 & 244.84 \\
\hline Sum of squares. & 89.77 & 32117.243 & $8569.65 \cdot 10^{6}$ & 146.748 & 481.54 & 43335602.82 & 978.73 \\
\hline Square roots & 9.475 & 179.213 & 92572.393 & 12.114 & 21.94 & 6582.98 & 31.29 \\
\hline
\end{tabular}

7c. Objectives divided by their square roots and MOORA

\begin{tabular}{|lccccccc|cc|c|}
\hline & $\boldsymbol{x}_{1}$ & $\boldsymbol{x}_{2}$ & $\boldsymbol{x}_{3}$ & $\boldsymbol{x}_{4}$ & $\mathrm{x} 5$ & $\boldsymbol{x}_{6}$ & $\boldsymbol{x}_{7}$ & total & rank \\
\hline ceiling 1 & 0.206 & 0.323 & 0.323 & 0.671 & 0.306 & 0.306 & 0.474 & -0.973 & $\mathbf{5}$ \\
\hline ceiling 2 & 0.353 & 0.363 & 0.363 & 0.453 & 0.426 & 0.426 & 0.383 & -0.356 \\
\hline ceiling 3 & 0.422 & 0.418 & 0.418 & 0.390 & 0.461 & 0.461 & 0.408 & -0.292 & $\mathbf{4}$ \\
\hline ceiling 4 & 0.496 & 0.502 & 0.502 & 0.337 & 0.490 & 0.490 & 0.460 & -0.325 \\
\hline ceiling 5 & 0.640 & 0.581 & 0.581 & 0.280 & 0.522 & 0.522 & 0.500 & -0.258 & $\mathbf{2}$ \\
\hline
\end{tabular}

7d. Reference point theory with ratios: coordinates of the reference point equal to the maximal objective values

\begin{tabular}{cccccccc}
\hline & $\boldsymbol{x}_{1}$ & $\boldsymbol{x}_{2}$ & $\boldsymbol{x}_{3}$ & $\boldsymbol{x}_{4}$ & $\boldsymbol{x}_{5}$ & $\boldsymbol{x}_{6}$ & $\boldsymbol{x}_{7}$ \\
\hline $\boldsymbol{r}_{\boldsymbol{i}}$ & 0.640 & 0.323 & 0.323 & 0.280 & 0.522 & 0.522 & 0.383 \\
\hline
\end{tabular}

7e. Reference point theory: deviations from the reference point

\begin{tabular}{|lccccccc|ccc|}
\hline & $\boldsymbol{x}_{1}$ & $\boldsymbol{x}_{2}$ & $\boldsymbol{x}_{3}$ & $\boldsymbol{x}_{4}$ & $\boldsymbol{x}_{5}$ & $\boldsymbol{x}_{6}$ & $\boldsymbol{x}_{7}$ & $\max$ & Rank min \\
\hline ceiling 1 & 0.434 & 0.000 & 0.000 & 0.391 & 0.216 & 0.216 & 0.091 & 0.434 & $\mathbf{5}$ \\
\hline ceiling 2 & 0.287 & 0.040 & 0.040 & 0.173 & 0.096 & 0.096 & 0.000 & 0.287 & $\mathbf{4}$ \\
\hline ceiling 3 & 0.217 & 0.096 & 0.096 & 0.111 & 0.061 & 0.061 & 0.026 & 0.218 \\
\hline ceiling 4 & 0.144 & 0.180 & 0.180 & 0.057 & 0.031 & 0.031 & 0.078 & 0.180 & $\mathbf{2}$ \\
\hline ceiling 5 & 0.000 & 0.258 & 0.258 & 0.000 & 0.000 & 0.000 & 0.118 & 0.258 \\
\hline
\end{tabular}

Table 7'. The full Multiplicative Form

\begin{tabular}{|ccccccccccc}
\hline & $\mathrm{A}$ & $\mathrm{B}$ & $\mathrm{C}$ & $\mathrm{D}$ & $\mathrm{E}$ & $\mathrm{F}$ & $\mathrm{G}$ & $\mathrm{H}$ & $\mathrm{I}$ \\
& $\mathrm{max}$ & $\min$ & $\mathrm{C}=\mathrm{A}: \mathrm{B}$ & $\min$ & $\mathrm{E}=\mathrm{C}: \mathrm{D}$ & $\min$ & $\mathrm{G}=\mathrm{E}: \mathrm{F}$ & $\max$ & $\mathrm{I}=\mathrm{G} \cdot \mathrm{H}$ \\
\hline ceiling 1 & 1.95 & 57.80 & 0.034 & 29856.59 & $1.132 \cdot 10^{-6}$ & 8.13 & $1.392 \cdot 10^{-7}$ & 6.71 & $9.34 \cdot 10^{-7}$ \\
\hline ceiling 2 & 3.34 & 65.00 & 0.052 & 33575.75 & $1.533 \cdot 10^{-6}$ & 5.49 & $2.791 \cdot 10^{-7}$ & 9.35 & $2.61 \cdot 10^{-6}$ \\
\hline ceiling 3 & 4.00 & 75.00 & 0.053 & 38741.25 & $1.377 \cdot 10^{-6}$ & 4.73 & $2.911 \cdot 10^{-7}$ & 10.11 & $2.94 \cdot 10^{-6}$ \\
\hline ceiling 4 & 4.70 & 90.00 & 0.052 & 46489.50 & $1.122 \cdot 10^{-6}$ & 4.08 & $2.750 \cdot 10^{-7}$ & 10.76 & $2.96 \cdot 10^{-6}$ \\
\hline ceiling 5 & 6.06 & 104.05 & 0.058 & 53747.03 & $1.084 \cdot 10^{-6}$ & 3.39 & $3.197 \cdot 10^{-7}$ & 11.45 & $3.66 \cdot 10^{-6}$ \\
\hline
\end{tabular}

\begin{tabular}{cccccc|}
\hline $\mathrm{J}$ & $\mathrm{K}$ & $\mathrm{L}$ & $\mathrm{M}$ & \multirow{2}{*}{ Result } & \multirow{2}{*}{ Project } \\
\cline { 1 - 4 } $\max$ & $\mathrm{K}=\mathrm{I} \cdot \mathrm{J}$ & $\min$ & $\mathrm{M}=\mathrm{K}: \mathrm{L}$ & & \\
\hline 2012.93 & $0.19 \cdot 10^{-2}$ & 14.83 & $0.127 \cdot 10^{-3}$ & 5 & ceiling 1 \\
\hline 2804.91 & $0.73 \cdot 10^{-2}$ & 11.97 & $0.612 \cdot 10^{-3}$ & 4 & ceiling 2 \\
\hline 3032.90 & $0.89 \cdot 10^{-2}$ & 12.77 & $0.699 \cdot 10^{-3}$ & 2 & ceiling 3 \\
\hline 3227.89 & $0.96 \cdot 10^{-2}$ & 14.40 & $0.663 \cdot 10^{-3}$ & 3 & ceiling 4 \\
\hline 3434.89 & $0.13 \cdot 10^{-2}$ & 15.65 & $0.804 \cdot 10^{-3}$ & 1 & ceiling 5 \\
\hline
\end{tabular}




\section{Annex C}

Table 8. MOORA applied on 5 windows alternatives with 7 conditions

8a. Matrix of responses of alternatives on objectives: $\left(x_{i j}\right)$

\begin{tabular}{|lccccccc|}
\hline & $\boldsymbol{x}_{1}$ & $\boldsymbol{x}_{2}$ & $\boldsymbol{x}_{3}$ & $\boldsymbol{x}_{4}$ & $\boldsymbol{x}_{5}$ & $\boldsymbol{x}_{6}$ & $\boldsymbol{x}_{7}$ \\
\cline { 2 - 7 } & $\max$ & $\min$ & $\min$ & $\min$ & $\max$ & $\max$ & min \\
\hline windows 1 & 0.588 & 202.31 & 102656.14 & 46.44 & 69.14 & 20741.31 & 4.95 \\
\hline windows 2 & 0.625 & 216.76 & 55989.11 & 55.77 & 59.81 & 17942.40 & 3.12 \\
\hline windows 3 & 0.625 & 216.76 & 109988.36 & 43.71 & 71.87 & 21560.28 & 5.10 \\
\hline windows 4 & 0.833 & 245.66 & 63453.98 & 50.21 & 65.37 & 19610.35 & 3.24 \\
\hline windows 5 & 0.833 & 245.66 & 124652.80 & 32.78 & 82.80 & 24839.17 & 5.02 \\
\hline
\end{tabular}

8 b. Sum of squares and their square roots

\begin{tabular}{|c|c|c|c|c|c|c|c|}
\hline & $x_{1}$ & $x_{2}$ & $x_{3}$ & $x_{4}$ & $x_{5}$ & $x_{6}$ & $x_{7}$ \\
\hline windows 1 & 0.35 & 40929.34 & $10538.28 \cdot 10^{6}$ & 2156.67 & 4780.34 & $430.20 \cdot 10^{6}$ & 24.50 \\
\hline windows 2 & 0.39 & 46984.90 & $3134.78 \cdot 10^{6}$ & $3 \quad 110.29$ & 3577.24 & $321.93 \cdot 10^{6}$ & 9.74 \\
\hline windows 3 & 0.39 & 46984.90 & $12097.44 \cdot 10^{6}$ & 1910.56 & 5165.30 & $464.85 \cdot 10^{6}$ & 26.02 \\
\hline windows 4 & 0.69 & $60 \quad 348.84$ & $4026.41 \cdot 10^{6}$ & 2521.04 & 4273.24 & $384.57 \cdot 10^{6}$ & 10.47 \\
\hline windows 5 & 0.69 & 60348.84 & $15538.32 \cdot 10^{6}$ & 1074.53 & 6855.84 & $616.99 \cdot 10^{6}$ & 25.18 \\
\hline Sum of squares. & 2.52 & 255596.80 & $45335.23 \cdot 10^{6}$ & 10773.10 & 24651.95 & $2218.52 \cdot 10^{6}$ & 95.91 \\
\hline Square roots & 1.59 & 505.57 & 212920.71 & 103.79 & 157.01 & $47 \quad 101.25$ & 9.79 \\
\hline
\end{tabular}

8c. Objectives divided by their square roots and MOORA

\begin{tabular}{|lrrrrrrr|r|r|}
\hline & $\boldsymbol{x}_{1}$ & $\boldsymbol{x}_{2}$ & $\boldsymbol{x}_{3}$ & $\boldsymbol{x}_{4}$ & $\boldsymbol{x}_{5}$ & $\boldsymbol{x}_{6}$ & $\boldsymbol{x}_{7}$ & total & rank \\
\hline windows 1 & 0.371 & 0.400 & 0.482 & 0.447 & 0.440 & 0.440 & 0.505 & -0.584 & $\mathbf{5}$ \\
\hline windows 2 & 0.394 & 0.429 & 0.263 & 0.537 & 0.381 & 0.381 & 0.319 & -0.392 & $\mathbf{3}$ \\
\hline windows 3 & 0.394 & 0.429 & 0.517 & 0.421 & 0.458 & 0.458 & 0.521 & -0.578 & $\mathbf{4}$ \\
\hline windows 4 & 0.525 & 0.486 & 0.298 & 0.484 & 0.416 & 0.416 & 0.330 & -0.240 & $\mathbf{1}$ \\
\hline windows 5 & 0.525 & 0.486 & 0.585 & 0.316 & 0.527 & 0.527 & 0.512 & -0.320 & $\mathbf{2}$ \\
\hline
\end{tabular}

$8 \mathrm{~d}$. Reference point theory with ratios: coordinates of the reference point equal to the maximal objective values

\begin{tabular}{rrrrrrrr}
\hline & \multicolumn{1}{c}{$\boldsymbol{x}_{1}$} & $\boldsymbol{x}_{2}$ & $\boldsymbol{x}_{3}$ & $\boldsymbol{x}_{4}$ & $\boldsymbol{x}_{5}$ & $\boldsymbol{x}_{6}$ & $\boldsymbol{x}_{7}$ \\
\hline $\boldsymbol{r}_{\boldsymbol{i}}$ & 0.525 & 0.400 & 0.263 & 0.316 & 0.527 & 0.527 & 0.319 \\
\hline
\end{tabular}

8e. Reference point theory: deviations from the reference point

\begin{tabular}{|lrrrrrrr|r|r|}
\hline & $\boldsymbol{x}_{1}$ & $\boldsymbol{x}_{2}$ & $\boldsymbol{x}_{3}$ & $\boldsymbol{x}_{4}$ & $\boldsymbol{x}_{5}$ & $\boldsymbol{x}_{6}$ & $\boldsymbol{x}_{7}$ & $\max$ & Rank min \\
\hline windows 1 & 0.155 & 0.000 & 0.219 & 0.132 & 0.087 & 0.087 & 0.187 & 0.219 & $\mathbf{2}$ \\
\hline windows 2 & 0.131 & 0.029 & 0.000 & 0.221 & 0.146 & 0.146 & 0.000 & 0.221 & $\mathbf{3}$ \\
\hline windows 3 & 0.131 & 0.029 & 0.254 & 0.105 & 0.070 & 0.070 & 0.202 & 0.254 & $\mathbf{4}$ \\
\hline windows 4 & 0.000 & 0.086 & 0.035 & 0.168 & 0.111 & 0.111 & 0.012 & 0.168 & $\mathbf{1}$ \\
\hline windows 5 & 0.000 & 0.086 & 0.322 & 0.000 & 0.000 & 0.000 & 0.194 & 0.322 & $\mathbf{5}$ \\
\hline
\end{tabular}

Table 8'. The full Multiplicative Form

\begin{tabular}{|ccccccccccc}
\hline & $\mathrm{A}$ & $\mathrm{B}$ & $\mathrm{C}$ & $\mathrm{D}$ & $\mathrm{E}$ & $\mathrm{F}$ & $\mathrm{G}$ & $\mathrm{H}$ & $\mathrm{I}$ \\
& $\mathrm{max}$ & $\min$ & $\mathrm{C}=\mathrm{A}: \mathrm{B}$ & $\min$ & $\mathrm{E}=\mathrm{C}: \mathrm{D}$ & $\min$ & $\mathrm{G}=\mathrm{E}: \mathrm{F}$ & $\max$ & $\mathrm{I}=\mathrm{G} \cdot \mathrm{H}$ \\
\hline windows 1 & 0.588 & 202.31 & 0.0029 & 102656.14 & $2.83 \cdot 10^{-8}$ & 46.44 & $6.1 \cdot 10^{-10}$ & 69.14 & $4.217 \cdot 10^{-8}$ \\
\hline windows 2 & 0.625 & 216.76 & 0.0029 & 55989.11 & $5.15 \cdot 10^{-8}$ & 55.77 & $9.23 \cdot 10^{-10}$ & 59.81 & $5.523 \cdot 10^{-8}$ \\
\hline windows 3 & 0.625 & 216.76 & 0.0029 & 109988.36 & $2.62 \cdot 10^{-8}$ & 43.71 & $6 \cdot 10^{-10}$ & 71.87 & $4.31 \cdot 10^{-8}$ \\
\hline windows 4 & 0.833 & 245.66 & 0.0034 & 63453.98 & $5.35 \cdot 10^{-8}$ & 50.21 & $1.06 \cdot 10^{-9}$ & 65.37 & $6.96 \cdot 10^{-8}$ \\
\hline windows 5 & 0.833 & 245.66 & 0.0034 & 124652.80 & $2.72 \cdot 10^{-8}$ & 32.78 & $8.3 \cdot 10^{-10}$ & 82.80 & $6.87 \cdot 10^{-8}$ \\
\hline
\end{tabular}

\begin{tabular}{cccc|c|c|}
\hline $\mathrm{J}$ & $\mathrm{K}$ & $\mathrm{L}$ & $\mathrm{M}$ & \multirow{2}{*}{ Result } & \multirow{2}{*}{ Project } \\
\hline max & $\mathrm{K}=\mathrm{I} \cdot \mathrm{J}$ & $\min$ & $\mathrm{M}=\mathrm{K}: \mathrm{L}$ & & \\
\hline 20741.31 & $0.09 \cdot 10^{-2}$ & 4.95 & $0.177 \cdot 10^{-3}$ & $\mathbf{5}$ & windows 1 \\
\hline 17942.40 & $0.10 \cdot 10^{-2}$ & 3.12 & $0.318 \cdot 10^{-3}$ & $\mathbf{3}$ & windows 2 \\
\hline 21560.28 & $0.09 \cdot 10^{-2}$ & 5.10 & $0.182 \cdot 10^{-3}$ & $\mathbf{4}$ & windows 3 \\
\hline 19610.35 & $0.14 \cdot 10^{-2}$ & 3.24 & $0.422 \cdot 10^{-3}$ & $\mathbf{1}$ & windows 4 \\
\hline 24839.17 & $0.17 \cdot 10^{-2}$ & 5.02 & $0.340 \cdot 10^{-3}$ & $\mathbf{2}$ & windows 5 \\
\hline
\end{tabular}


Willem Karel M. BRAUERS was graduated as: PhD in economics (Un. of Leuven), Master of Arts (in economics) of Columbia Un. (New York), Master in Management and Financial Sciences, in Political and Diplomatic Sciences and Bachelor in Philosophy (Un. of Leuven). He is professor at the Faculty of Applied Economics and at the Institute for Development Policy and Management of the University of Antwerp. Previously, he was professor at the University of Leuven, the Military Staff College, the School of Military Administrators, and the Antwerp Business School. He was a research fellow in several American institutions like Rand Corporation, the Pentagon, the Institute for the Future, the Futures Group and extraordinary advisor to the Center for Economic Studies of the University of Leuven. He was consultant in the public sector, such as the Belgian Department of National Defense, the Department of Industry in Thailand, the project for the construction of a new port in Algeria (the port of Arzew) and in the private sector such as the international seaport of Antwerp and in electrical works. He was Chairman of the Board of Directors of SORCA Ltd. Brussels, Management Consultants for Developing Countries, linked to the world-wide group of ARCADIS and Chairman of the Board of Directors of MARESCO Ltd. Antwerp, Marketing Consultants. At the moment he is General Manager of CONSULTING, Systems Engineering Consultants. Brauers is member of many international scientific organizations. His specialization covers: Optimizing Techniques with Several Objectives, Forecasting Techniques and Public Sector Economics such as for National Defense and for Regional Sub-optimization and Input-Output Techniques. His scientific publications consist of seventeen books and hundreds of articles and reports.

Modestas KRACKA. PhD student (civil engineering). Dept of Construction Technology and Management, Gediminas Technical University (VGTU), Vilnius Lithuania. Master of Science (Civil engineering), VGTU, 2007. Bachelor of Science (Urban engineering), VGTU, 2005. Research interests: Construction process, usage and maintenance of buildings, Building Construction Technology, Building Renovation. Access to local technical regulations for building renovation, particularly heritage buildings.

Edmundas Kazimieras ZAVADSKAS is head of the Research Institute of Internet and Intelligent Technologies and head of the Department of Construction Technology and Management at Vilnius Gediminas Technical University, Vilnius, Lithuania. He has a PhD in building structures (1973) and DrSc (1987) in building technology and management. He is a member of the Lithuanian and several foreign Academies of Sciences. He is Doctore Honoris Causa at Poznan, SaintPetersburg, and Kiev universities. He is a member of international organizations and has been a member of steering and programme committees at many international conferences. E. K. Zavadskas is a member of editorial boards of several research journals. He is author and co-author of more than 400 papers and a number of monographs. Research interests are: building technology and management, decision-making theory, automation in design and decision support systems. 